UC.25

Issued: Sepiomber 1977

\title{
LA-6918-MS
}

\section{Zero and Low Coefficient of Thermal Expansion Polycrystalline Oxides}

\author{
S. R. Skaggs
}
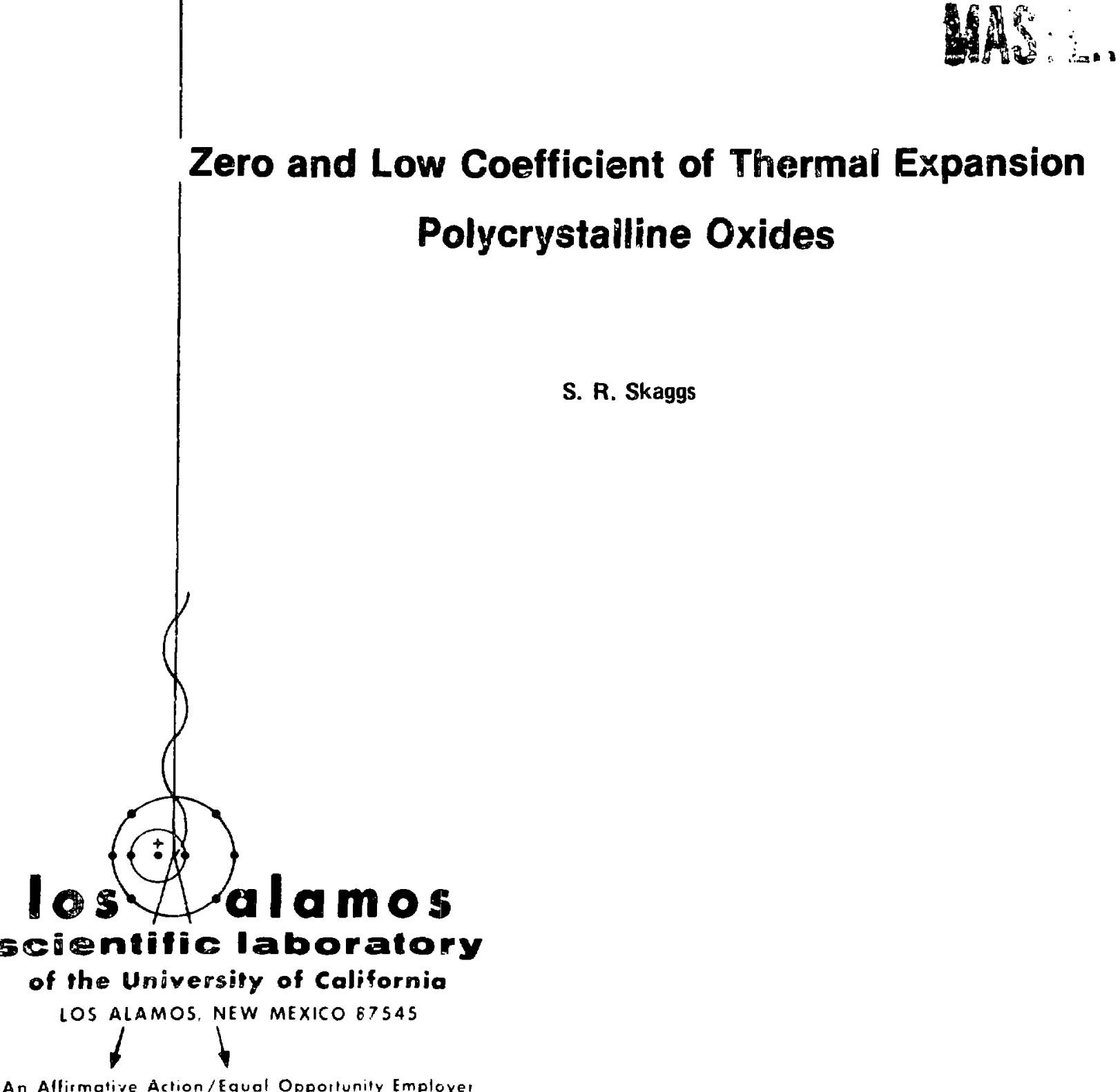

An Allirmative Action/Equal Oppollunily Employer 


\title{
ZERO AND LOW COEFFICIENT OF THERMAL EXPANSION POLYCRYSTA I.LINE OXIDES
}

by

\author{
S. R. Skagg8
}

\begin{abstract}
Polycrystalline oxide systems with zero to low coefficient of thermal expansion (CTE) investigated by the gurthor include hafmia-titamia and hafnia. The CTE for 30-40 mol\% $\mathrm{TiO}_{2}$ in $\mathrm{HIFO}_{2}$ is $\leq 1 \times 10 \% \mathrm{O}$, while for other conpositions in the range $25-60 \mathrm{~mol} \%$ it is $\sim 4 \times 10^{-\theta} /{ }^{\circ} \mathrm{C}$. An investigation of the CTE of $99.999 \% \mathrm{HfO}_{2}$ yielded a value of $4.6 \times 10^{-6} /{ }^{\circ} \mathrm{C}$ from room temperature to $1000^{\circ} \mathrm{C}$. Correlation with data on $\mathrm{HfO}_{2}$ by other investigators shows a definite relationship between the $\mathrm{CTE}$ and the amount of $\mathrm{ZrO}_{2}$ present. Data are listed for comparison of the CTE of several cher polycrystalline oxides investigated by Holtombe et Oak Ridge.
\end{abstract}

\section{RESUME}

\section{COEFICIENT ZERO ET BAS D'OXYIES POLYCRYSTALLINS DE DILATATION THERMIQUE}

Les systèmes d'oxydes polycrystallins avec le coefificient zéro a bas de dilatation thermique (CDT) étudiés par l'auteur comprennent les oxydes d'hafnium-dioxydes de titane et les oxydes d'hafnium. Le CDT pour 30-40 moles\% $\mathrm{TiO}_{2}$ en $\mathrm{HfO}_{2}$ est $\leq 1 \times 1$. $1 /{ }^{\circ} \mathrm{C}$, tandis que pour d'autres compositions dans le domaine de $25-60$ moles $\%$ il est $\sim 4 \times 10^{-6} /{ }^{\circ} \mathrm{C}$. Une étude du CDT de $99,999 \% \mathrm{HfO}_{2}$ a donné une valeur de $4,6 \times 10^{-6} /{ }^{\circ} \mathrm{C}$ de la température ambiante jusqu'a $1000^{\circ} \mathrm{C}$. Une correlation avec les données sur $\mathrm{HfO}_{2}$ par d'autres chercheurs montre un rapport défini entre le CDT et la quantité de $\mathrm{Z}_{\mathrm{rO}} \mathrm{O}_{2}$ présente. Les données sont portées sur une liste pour comparer lẹ CDT de quelques autres oxydes polycrystalliny etudiés par Milcombe à Oak Ridge.

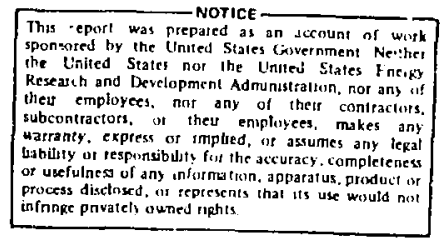




\section{Hafmir-Titamia}

Considerable interest has been expressed in hafnia-titania compounds for use in flame tube liners in manufacturing processes and steam ganerators, and for ducts and heat exchangers in MHD systems. The $\mathrm{HfO}_{2}-\mathrm{TiO}_{2}$ system is one of the first polycrystalline oxide systems to be studisd extonsively because of the unusual property of low coefficient of thermal expansion (CTE). In 1960 Goaina et al ${ }^{1}$ observed the low CTE in their study in the USSR. In the U.S. during the same year Simpson ${ }^{2}$ reported that compositions from 30 - to 40mol\% $\mathrm{TiO}_{3}$ have zero or slightly negative CTEs

Ten years later Lynch and Morosin in their study of the expansion, compressibility, and polymorphism of 37 - and $50-\mathrm{mol}_{\mathrm{O}} \mathrm{TiO}_{2}$ idencified the b-axis in the orthorhombic system as heving a strongly negatiye TTE while the other two axes remained positive. A more extensive investigation was conducted by $\mathbb{R}$ uh et al ${ }^{4}$ who studied the CTE of 0 - to $60-\mathrm{mol}^{2} \mathrm{TiO}_{3}$ in $\mathrm{HfO}_{3}$ in $2.5-\mathrm{mol}^{2}$ increments. They determined that single-phase ot thorhombic hafnium titanate exists in the range $36-$ to $53-\mathrm{mol} \%$ $\mathrm{TiO}_{2}$. Thermal erpansion was neasured as a function of composition, and very low coefficients of $\leq 1$ x $10^{-0} /{ }^{\circ} \mathrm{C}$ were found in the $30-$ to $40-\mathrm{mol}^{\circ} \mathrm{TiO}_{2}$ range. Moderate coefficients of $\simeq 4 \times 10^{-0} /{ }^{\circ} \mathrm{C}$ were found for the 25-, 45-, 50-, and 60- $\mathrm{mol}_{\mathrm{C}} \mathrm{NiU}_{2} \mathrm{com}$ positions. They attributed the low expansion behavior to microcracking. They also presented a phase diagram for the $\mathrm{HfO}_{2}-\mathrm{TiO}_{2}$. system, shown in Fig. 1. It is interesting to note from the phase diagram that this oxside can be: heated from room temperature (RT) to over $2000^{\circ} \mathrm{C}$ across a brokd range of compositions and not undergo a single polymorphic transformation. At about $48 \mathrm{~mol} \%$ the material can be heated to $\sim 2800^{\circ} \mathrm{C}$ with no crystallographic change.

Discontinuities in other properties were found by other investigators in the same composition range. For example, Hoagland $e^{t}$ al ${ }^{b}$ reported that the strength and the mudulus were nearly constant in the $30-$ to $40-\mathrm{mol}_{\%} \mathrm{TiO}_{2}$ range and increased by a facior of 2 in the $45-$ to $50-\mathrm{mol}^{2} \mathrm{TiO}_{2}$ range.

Anderson et al ${ }^{6}$ began $\varepsilon$. study* of 25 - to $60-\mathrm{mol} \%$ $\mathrm{TiO}_{2}$ in $\mathrm{HfO}_{3}$ to determine as a function of composi-

\footnotetext{
-The author was a coinvestigator in this study.
}

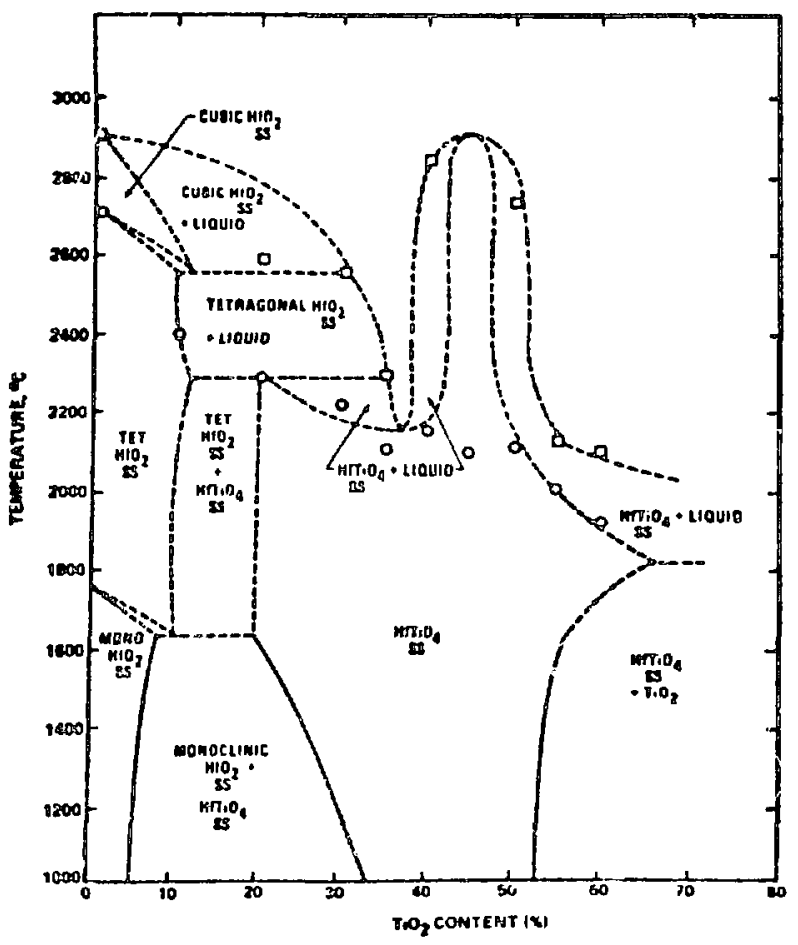

Fig. 1.

Hafnia-titania phase diagram as proposed by Ruh et al." (with permission).

tion 1) the coefficient of thermal expansion, 2) the dynamic response to pulsed energy deposition, and 3) the Grumeisen parameter determined indeper. dentiy using the thermal expansion data (static) and the pulsed deposition data (dynamic).

The CTE was determined from room temperature to $800^{\circ} \mathrm{C}$ using a Fizeau interferometer* on hotpressed samples $1.5 \mathrm{~mm}$ square by $5 \mathrm{~mm}$ long. Several thermal cycles were imposed or ' he samples of each composition of 25-, 30-, 36.75-, 40-, 45-, 50-, and $60-\mathrm{mol} \% \mathrm{TiO}_{2}$. The CTE data fall into two groups. The data for 30-, 36.75-, and $40-\mathrm{mol} \% \mathrm{TiO}_{2}$

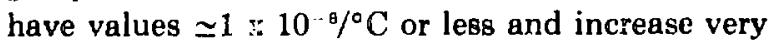
slightly with increasing $\mathrm{TiO}_{8}$ content. The data for $25-, 45-, 50$-, and $60-\mathrm{mol}^{2} \mathrm{TiO}_{2}$ have values of $\geq 4 \mathrm{x}$ $10^{-8} /{ }^{\circ} \mathrm{C}$, see Fig. 2.

Thermal cycling of the samples yielded inieresting results. On the secon's theris al cycle the CTE for the $25-\mathrm{mol}_{\%} \mathrm{TiO}_{2}$ sample duplicated the 


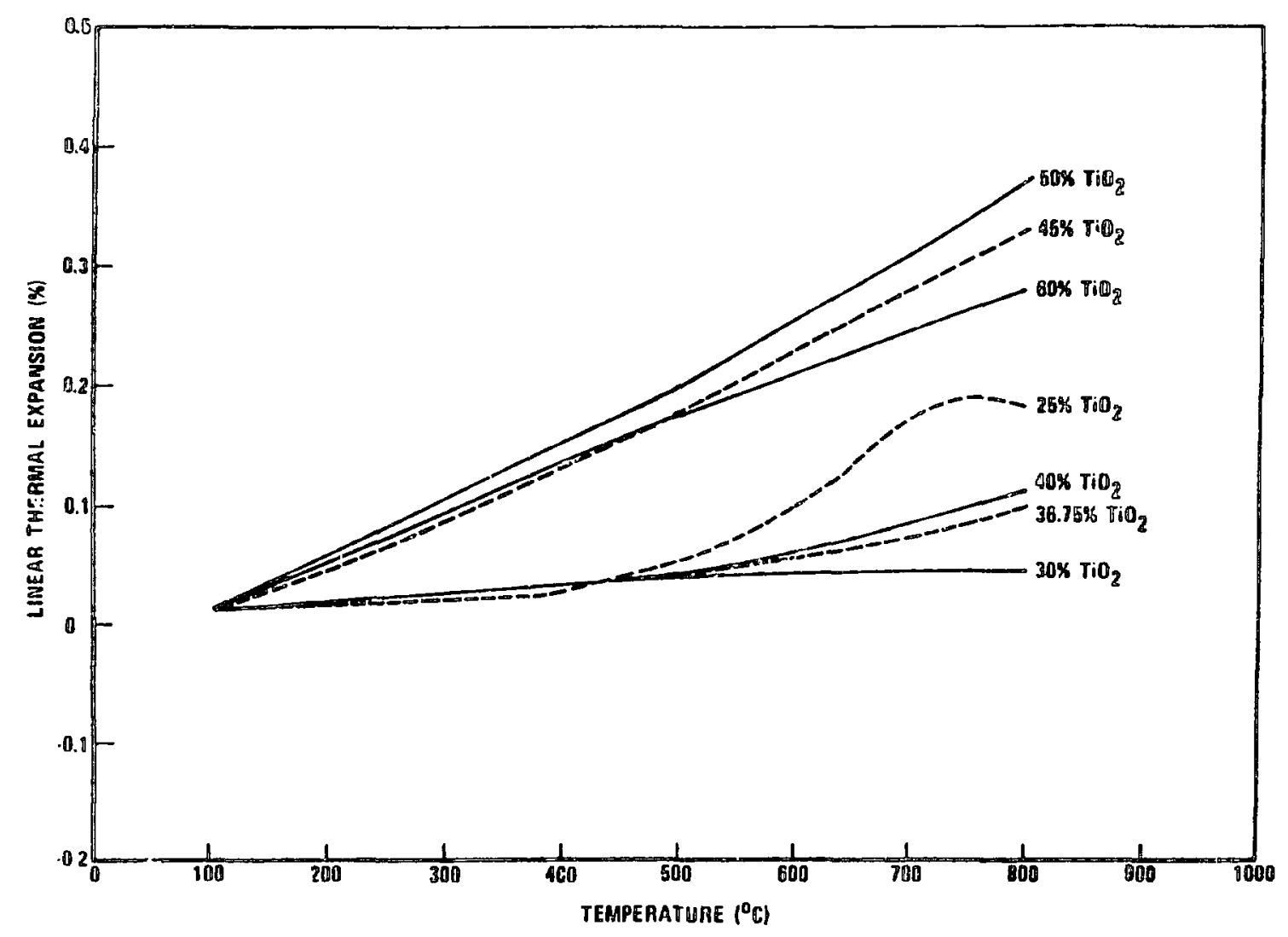

Fig. 2.

Thermal expansion of $\mathrm{HfO}_{2}-\mathrm{TiO}_{2}$ compositions us temperature. The curves are an average of at least five thermal cycles with exception of those mentioned above.

first curve. On the third cycle the CTE did not repeat hut doubled in value and the sample disintegrated. A second sample was cycled and it disintegrated on the third thermal cycle also. In contrast, the 30 - and $36.75-\mathrm{mcl}^{2} \mathrm{TiO}_{2}$ samples were cycled several more times and retained their integrity throughout the thermal cycling. This same contrast in behavior was auted in the earlier work by Ruh et al. ${ }^{4}$

For the dynamic response experiments, pulsed electron lieam energy deposition was used to generate stress waves in hot-pressed disks of the same material. The Nereus generator was described in the report by Anderson et al. The sample configuration used in this study is a $12.7-\mathrm{mm}$-diam, 0.4mm-thick $\mathrm{Hfr}_{3}-\mathrm{TiO}_{2}$ disk epoxied to a $25.4-\mathrm{mm}$ diam, 1.jo-mm-thick, fused- $\mathrm{SiO}_{2}$ disk with a silvered (mirror) rear surface. The electron beam is incident on and totally absorbed by the $\mathrm{HfO}_{2}-\mathrm{TiO}_{2}$ disk. The velocity-time history is measured with a displacement interferometer focused on the mirrored surface of the fused- $\mathrm{SiO}_{2}$ disk.

Experiments were run on the 30-, 36.75-, 40-, 45-, and $50-\mathrm{mol} \% \mathrm{TiO}_{2}$ compositions at incident fluences of 330 and $710 \mathrm{~kJ} / \mathrm{m}^{2}$. These fluences correspond to peak deposited energies of 0.58 and $1.25 \mathrm{MGy},{ }^{*}$ or peak temperatures of about 1100 and $2200^{\circ} \mathrm{C}$ (using approximate heat capacities). One or two experiments were conducted on each material at each fluence.

Figure 3 shows the peak free-surface velocities obtained for all five materials. It can be seen that the

\footnotetext{
$1 \mathrm{~J} / \mathrm{g}=1 \mathrm{kGy}$.

$1 \mathrm{MGy}($ megagray $)=1000 \mathrm{~J} / \mathrm{g}$.
} 


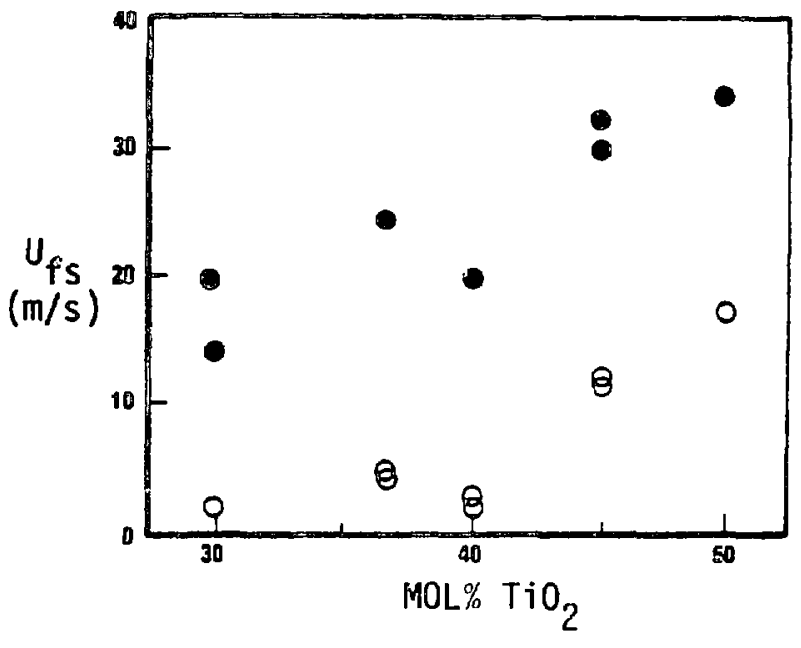

Fig. 3.

Peak free-surface velucities of $\mathrm{HfO}_{2}-\mathrm{TiO}_{2}$ samples bombarded with electrons of $\langle E\rangle=225$ keV.

trends in peals free-surface velocity are similar to the CTE data, i.e., the three compositions with 30 $40 \% \mathrm{TiO}_{2}$ have lower $\mathrm{U}_{\mathrm{fa}}$ than the $45-50 \% \mathrm{TiO}_{2} \mathrm{com}$ positions. In the high-fluence experiments the peak deposited energy (1.25 MGy) was approaching the melt energy of the materials (1.42 MGy). This, coupled with the higher amplitude of the stress waves, resulted in a front-surface spallation of an $\sim 0.03-\mathrm{mm}$ layer of the sample materials in every erperiment.

The measured peak free-surf ce velocity can be related to an averge Grüneisen perameter, $\Gamma$, through the wave velocity, $\mathrm{U}_{\mathrm{B}}$, and the peak deposited energy, $\mathbf{E}$, for the dynamic case.

$\Gamma=\frac{\mathrm{U}_{\mathrm{S}} \mathrm{U}_{\mathrm{fS}}}{\mathrm{E}}$.

A one-dimensional wave propagation computer code $^{7}$ is used to account for finite deposition time and the impedance mismatch, and thus obtain values for $\Gamma$ from our experimentul $U_{t a}$ data.

For the static case the Grüneisen parameter can be calculated from other material properties,

$$
\Gamma=3 \frac{\alpha K_{s}}{\rho C_{p}},
$$

with $\alpha$ the coefficient of linear expansion, $K_{\mathrm{B}}$ the isentropic bulk modulus, and $\mathrm{C}_{\mathrm{p}}$ the heat capacity at constant pressure. The values of $\alpha$ up to $800^{\circ} \mathrm{C}$ are given in Fig. 2, and $K_{a}$ and $C_{p}$ are known approximately from other sources. ${ }^{8}$ With these data, an average $\Gamma$ was calculated for the temperature range $23-800^{\circ} \mathrm{C}$. The values of $\Gamma$ calculated from CTE data and from the lower fluence dynamic response data (representing $\Gamma$ from $23-1100^{\circ} \mathrm{C}$ ) are plotted in Fig. 4.

There is fairly good agreement between the two methods for calculating the Grüneisen parameter. The discontinuous jump at $45 \mathrm{nol} \% \mathrm{TiO}_{2}$ is a confirmation of the change in the materials noted in other properties already described. Disagreement between the two methods for the data in Fig. 4 may appear large on a relative basis ( $>50 \%)$; however, on an absolute basis, when compared with normal materials, the agreement is quite good. For example, in a fully dense material of normal CTE the value of $\Gamma$ ranges from 1-3. Although the low value for this material is primarily related to the low CTE of the $\mathrm{HfO}_{2}-\mathrm{TiO}_{2}$ mixtures, a small portion can be attributed to porosity, for it takes some energy to close the pores as the stress wave passes through the material. Stress in the dynamic experiments of $0.1-0.3 \mathrm{GPa}$

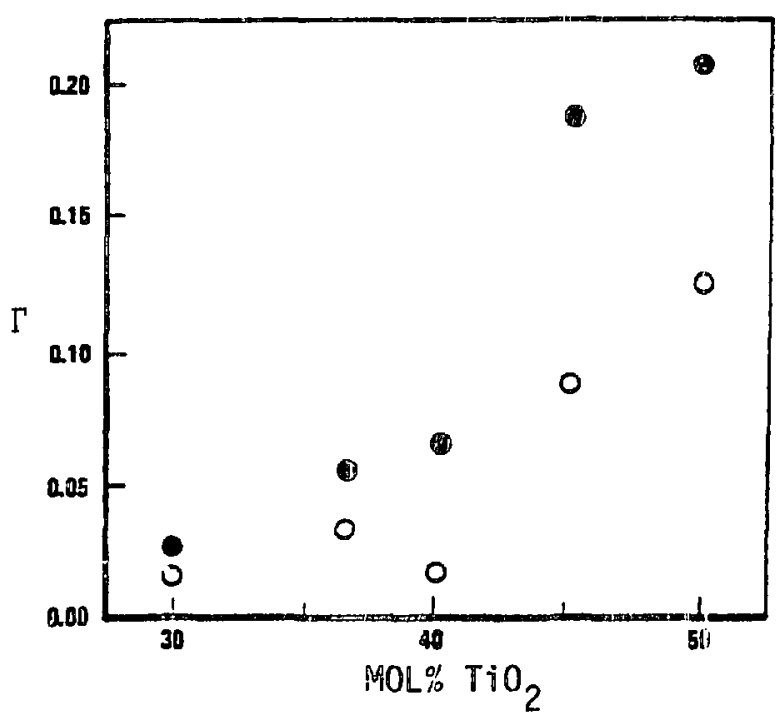

Fig. 4.

Grüneisen parameter as calculated from the static datu (black dots) and from the dynamic response data (open circles). 
was sufficient to cause some pore collapse, but the naterial was not treated as fully dense even after the energy deposition.

\section{Hafniя and Zirconia Systems}

After the investigations on the hafnia-titania system by Ruh et al' and Anderson et al, ${ }^{\circ}$ it was apparent that the end members of the system needed better understanding. Reed ${ }^{\theta}$ has worked with $\mathrm{TiO}_{2}$ quite extensively and has shown that it is difficult to obtain pure stoichiometric $\mathrm{TiO}_{2}$, although he has obtained many compositions between $\mathrm{Ti}$ metal and $\mathrm{TiO}_{2}$. Because of his extensive work on the $\mathrm{Ti}-\mathrm{O}$ system we decided to concentrate our investigations on the other end member, $\mathrm{HfO}_{2}$, which initially appeared to be a neglected area of study. A separate investigation was conducted on pure $\mathrm{ZrO}_{2}$ because it is isomorphous with $\mathrm{HfO}_{2}$ and it has been studied quite extensively.

Several méasurements on zirconia were performed after the initial meastirement was made on hafnia and were prompted by the iarge disagreement between our results and those of other investigators. Using two separate techniques, a Fizeau interferometer and a quartz dilatometer, we found the average value of the CTE of fairly pure $\mathrm{ZrO}_{2}$ to be $7.3 \times 10^{-\theta} /{ }^{\circ} \mathrm{C}$ in good agreement with the measurements of others.

Geller and Yavorsky, ${ }^{10}$ the first to study relatively pure $\mathrm{ZrO}_{2}$, found a CTE value of $7.3 \times 10^{-6} /{ }^{\circ} \mathrm{C}$ in heating and cooling over a range of $80-900^{\circ} \mathrm{C}$. Burdick and Hoskyns ${ }^{11}$ obtained a value of $7.24 \mathrm{x}$
$10^{-6} /{ }^{\circ} \mathrm{C}$ over the tempe;ature range from room temperature to $1075^{\circ} \mathrm{C}$ the monoclinic-tetragonal transformation). Grain and Campbell measured a value of $7.37 \times 10^{-0} /{ }^{\circ} \mathrm{C}$ over the temperature range of room temperature to $964^{\circ} \mathrm{C}$.

Several more measurements were made on the very pure (99.999\%) $\mathrm{HfO}_{2}$ samples.* The average bulk CTE was $4.6 \times 10^{-8} /{ }^{\circ} \mathrm{C}$ for several samples cycled as many as 10 times between room temperature and $1000^{\circ} \mathrm{C}$. Values for the axial expansion coefficients are shown in Table 1 . Note that there is a considerable disparity, about $30 \%$, between the axial expansion coefficient and the bulk CTE. We attribute this to microcracking because of the aigmoid behavior of the coefficient of thermal ex. pansion when plotted as a function of thermal cycles.

A scanning electron microscope (SEM) was used to try to view the microcracks in a similar fashion to those observed in the hafnia-titania system. We were unable to see the microcracks in the pure hafnia; however, the limits of resolution of the SEM were $\sim 0.03 \mu \mathrm{m}$.

In a review of the literature we found the CTE for $\mathrm{HfO}_{2}$ has been investigated by several groups. Curtis et al, ${ }^{12}$ Grain and Campbell, ${ }^{10}$ Ohynsty and Rose, "Patil and Subbareo, ${ }^{10}$ Filatov and FrankKamanetskii, ${ }^{16}$ and Stacy et $a l,{ }^{27}$ have stucied a range of compositions of $\mathrm{HfO}_{2}$. There is a variation of about a factor of 2 in the values of CTE quoted by each of the investigators. The study in which the

"Cerac-Pure, Mennminee Falls, Wisconsin, USA.

\section{TABLE I}

\section{$\mathrm{HFO}_{2}$ LATTICE EXPANSION COEFFICIENTS, $\times 10^{-6} /{ }^{\circ} \mathrm{C}$}

\begin{tabular}{|c|c|c|c|c|}
\hline$\left({ }^{\circ} \mathrm{C}\right)$ & $\boldsymbol{\alpha}_{\mathrm{a}}$ & $\alpha_{b}$ & $\boldsymbol{\alpha}_{\mathrm{c}}$ & $1 / 3\left(\alpha_{\mathrm{a}}+\alpha_{\mathrm{b}}+\alpha_{\mathrm{c}}\right)$ \\
\hline 27 & $\ldots$ & ... & ... & \\
\hline 250 & b. 397 & -1.471 & 11.866 & 5.597 \\
\hline 500 & 7.841 & 0.653 & 13.998 & 7.497 \\
\hline 750 & 7.607 & 0.294 & 12.093 & 6.665 \\
\hline 1000 & 7.510 & 0.059 & 12.355 & 6.641 \\
\hline 1250 & 7.338 & -1.347 & 12.363 & 6.451 \\
\hline
\end{tabular}


author participated showed still a different value for the CT' of $99.999 \% \mathrm{HfO}_{2}, 4-6 \times 10^{-\theta} /{ }^{\circ} \mathrm{C}$.

Examination of all of the data available from each sample including this study showed quite a wide variation in the zirconia content. The CI'E for each sample was plotted against zirconia content in the sample and the result is shown in Fig. 5 . With the exception of the value obtained by Patil and Subbarao, all of the data lie on the same line on semilogarithmic paper with the material in this study being the purest and therefore the lowest in CTE. Apparently there is a strong influence exerted on the CTE of $\mathrm{HfO}_{2}$ by $\mathrm{Zr}$ substituted in specific lattice sites for Hf. The relationship shown in Fig. 3 also suggests that the thermal expansion of $\mathrm{HfO}_{2}$ can be tailored to a specific value by doping the material with $\mathrm{ZrO}_{2}$ in a controlled way.

\section{Other Systems}

Simultaneously with the work at LASL and Air Force Materials Laboratory (AFML), there was a stury conducted by Holcombe and his coworkers ${ }^{18}$ at the Union Carbide Corporation (UCC) in Oak Ridge. This group surveyed the various combinations of oxides that might exhibit low or zero CTE behavior. They first explored the $\mathrm{HfO}_{2}-\mathrm{TiO}_{2}$ system

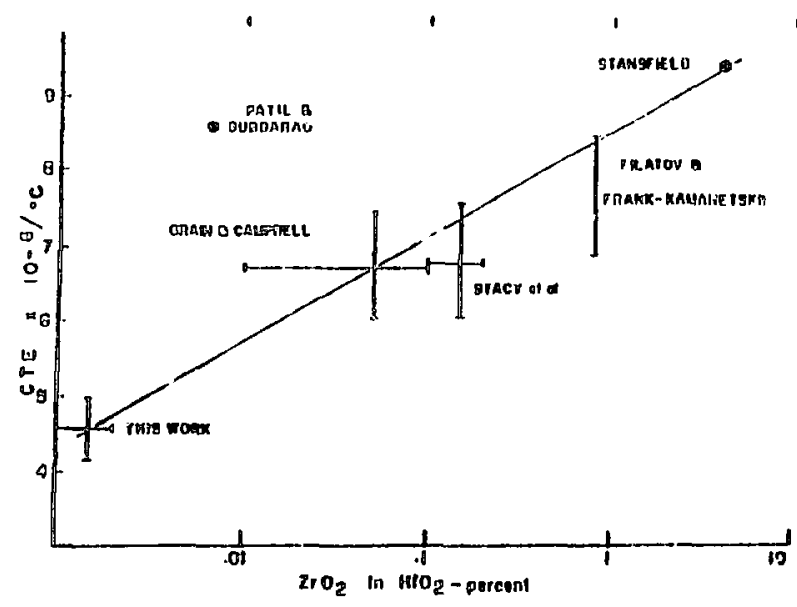

Fig. 5.

Bulk coefficient of thermal expansion of hafnia as a function of the impurity content of zirconia. as we did, and then progressed to the $\mathrm{Al}_{2} \mathrm{O}_{8}-\mathrm{TiO}_{2}$ system. Finally they extended their investigation to other systems which might possibly contain low expanding materials. The choice of the new systems was made using the following considerations. They listed the single oxides which have low expansions: $\mathrm{TiO}_{2}, \mathrm{Nb}_{2} \mathrm{O}_{5}, \mathrm{Ta}_{2} \mathrm{O}_{6}, \mathrm{SnO}_{3}$, and $\mathrm{WO}_{3}$. They combined these oxides with those that had a history of a low CTE by themselves or in combination with the first group of oxides. The ese are $\mathrm{HfO}_{2}, \mathrm{ZrO}_{2}, \mathrm{Al}_{2} \mathrm{O}_{3}$, $\mathrm{Y}_{2} \mathrm{O}_{3}$, and $\mathrm{NiO}$. All of this latter group have high melting points, and were chosen because low expanding systems had been reported elsewhere in the literature.

Holcombe attempted first to identify the materials or cornbinations that had characteristic low expansions, and then to identify the mechanisms that cause the low expansions. Table II lists the oxides that ho investigated and reported in four categories; 1) isegative or zero CTE, 2) very low CTE $\left.\left(\leq 1 \times 10^{-\theta} /{ }^{\circ} \mathrm{C}\right), 3\right)$ low CTE $\left(1-4 \times 10^{-1 /} /{ }^{\circ} \mathrm{C}\right.$, and 4) intermediate CTE $\left(4-8 \times 10^{-8} /{ }^{\circ} \mathrm{C}\right)$. He also noted in passing but did not investigate several other materials, most of which are naturelly occurring minerals such as quartz and $\beta$-eucryptite, which have near zero or very low CTE.

\section{Sample Preparation}

A presentation of this kind would not be complete without some discussion of the methods of preparation and fabrication. Holcombe prepared his own powders by the technique described by Masdiyasni et al. ${ }^{19}$ LASL purchased powders prepared commercially. The distinguishing difference between the two is that the commercially prepared powders are typically $\sim 325$ mesh, whereas those prepared in the laboratory are $200-400 \mu \mathrm{m}$. This may have some influence on the characteristic behavior of the unal sample.

Holcombe pressed the fine powders into rods isostatically at $200 \mathrm{MPa}$ (300 $000 \mathrm{psi}$ ). The rods were sintered in flowing argon at $80 \% \mathrm{~T}_{m}$ for $4 \mathrm{~h}$ using alumina or boron nitride crucibles. Several steps were taken to characterize the material after fabrication into rods. Chemical analysis was done 
TAELE II

\section{LIST OF COMPOUINDS INVESTIGATED BY HOLCOMBE AND THEIR $\mathbb{C}$ JEFHICIENT OF THERMAL EXPANSION}

Compound

$\mathrm{Ta}_{2} \mathrm{O}_{6} \cdot \mathrm{WO}_{3}$

$55 \mathrm{Ta}_{2} \mathrm{O}_{\mathrm{n}} \cdot 45 \mathrm{WO}_{\mathrm{s}}$

$45 \mathrm{Ta}_{2} \mathrm{O}_{3} \cdot 55 \mathrm{WO}_{3}$

$37 \mathrm{Ta}_{2} \mathrm{O}_{6} \cdot 63 \mathrm{WO}_{3}$

$63 \mathrm{HfO}_{2} \cdot 37 \mathrm{TiO}_{3}$

$\mathrm{HfO}_{2} \cdot \mathrm{WO}_{3} \cdot \mathrm{Ta}_{\mathrm{B}} \mathrm{O}_{6}$

$\mathrm{HfO}_{2} \cdot \mathrm{Nb}_{2} \mathrm{O}_{6}$

$\mathrm{Al}_{2} \mathrm{O}_{3} \cdot \mathrm{TiO}_{2}$

$\mathrm{HfO}_{2} \cdot 3 \mathrm{Nb}_{2} \mathrm{O}_{6}$

$\mathrm{HfO}_{2} \cdot 3 \mathrm{Ta}_{2} \mathrm{O}_{6}$

$\mathrm{SnO}_{2} \cdot \mathrm{Ta}_{2} \mathrm{O}_{3}$

$\mathrm{HfO}_{2} \cdot \mathrm{TiO}_{2}$

$\mathrm{Nb}_{2} \mathrm{O}_{3} \cdot \mathrm{TiO}_{2}$

$\mathrm{Ta}_{2} \mathrm{O}_{5} \cdot \mathrm{TiO}_{2}$

$\mathrm{ZrO}_{2} \cdot \mathrm{Nb}_{2} \mathrm{O}_{6}$

$\mathrm{ZrO}_{2} \cdot 3 \mathrm{Nb}_{2} \mathrm{O}_{8}$

$63 \mathrm{Al}_{8} \mathrm{O}_{9} \cdot 37 \mathrm{TiO}_{3}$

$63\left(75 \mathrm{HfO}_{2} \cdot 25 \mathrm{ZrO}_{3}\right) 37 \mathrm{TiO}_{2}$
Binary/

Temary Cryatal System CTR

Negative or Zero

\begin{tabular}{|c|c|c|}
\hline $\bar{R}$ & & -324 \\
\hline $\mathbf{R}$ & incruant malt & -0.06 \\
\hline B & incongruent melt- & $\begin{array}{l}-0.0 \\
-20\end{array}$ \\
\hline & & -2.0 \\
\hline $\mathbf{B}$ & $\begin{array}{l}\text { this region of the } \\
\text { phase diagram }\end{array}$ & -0.7 \\
\hline $\mathrm{B}$ & ortho & $\sim 0$ \\
\hline $\mathrm{T}$ & ortho & $\sim 0$ \\
\hline \multicolumn{3}{|c|}{ (Very how $\leq 1 \times 10^{-8} /{ }^{\circ} \mathrm{C}$ ) } \\
\hline $\bar{B}$ & $\cdots$ & $<1$ \\
\hline B & ortho & 0.8 \\
\hline \multicolumn{2}{|c|}{$\left(\right.$ Low $\left.1-4 \times 10^{-6 / 0} \mathrm{C}\right)$} & \\
\hline $\mathbf{B}$ & -.. & 3.2 \\
\hline B & $\cdots$ & 3.36 \\
\hline B & monoclinic & 1.68 \\
\hline $\mathbf{B}$ & ortho & 3.59 \\
\hline $\mathbf{B}$ & monoclinic & 2.3 \\
\hline B & monoclinic & 3.4 \\
\hline B & $\ldots$ & 2.71 \\
\hline B & ... & 2.5 \\
\hline $\mathbf{B}$ & --- & 1.47 \\
\hline $\mathbf{T}$ & -.. & 2.24 \\
\hline
\end{tabular}

Negative or Zero

(Intermediate $4 .-8 \times 10^{-6}$ )

$\mathrm{HfO}_{2} \cdot \mathrm{Al}_{2} \mathrm{O}_{3}$

$\mathrm{HfO}_{2} \cdot \mathrm{Ta}_{2} \mathrm{O}_{3}$

$\mathrm{Al}_{2} \mathrm{O}_{5} \cdot \mathrm{Ta}_{2} \mathrm{O}_{3}$

$\mathrm{MgO} \cdot \mathrm{Ta}_{2} \mathrm{O}_{3}$

$\mathrm{NiO} \cdot \mathrm{Ta}_{2} \mathrm{O}_{0}$

$\mathrm{Y}_{2} \mathrm{O}_{3} \cdot \mathrm{TiO}_{2}$

$\mathrm{ZrO}_{2} \cdot \mathrm{Ta}_{2} \mathrm{O}_{\text {, }}$

$63\left(50 \mathrm{HfO}_{2}, 50 \mathrm{Al}_{2} \mathrm{O}_{8}\right)$.

$37 \mathrm{TiO}_{2}$

$\begin{array}{ccc}\text { B } & \cdots & 7.43 \\ \text { B } & \cdots & 4.82 \\ \text { B } & \text { ortho } & 4.90 \\ \text { B } & \text { tetra } & 6.79 \\ \text { B } & \text { tetra } & 4.10 \\ \text { B } & \text { ortho } & 8.77 \\ \text { B } & \cdots & 5.72 \\ \text { T } & -\cdots & 6.45\end{array}$


TABLE II (cont)

\begin{tabular}{|c|c|c|c|}
\hline Compound & $\begin{array}{l}\text { Binary/ } \\
\text { Ternary } \\
\end{array}$ & Crystal System & CTE $\times 10^{-\theta}$ \\
\hline $\begin{array}{c}63\left(25 \mathrm{HfO}_{2}, 75 \mathrm{Tr}_{2} \mathrm{O}_{8}\right) \\
37 \mathrm{TiO}_{2}\end{array}$ & $\mathrm{~T}$ & $\cdots$ & 5.31 \\
\hline $\begin{array}{l}\left.63\left(50 \mathrm{HfO}_{2}, 50 \mathrm{ZrO}\right)_{2}\right) \\
37 \mathrm{TiO}_{2}\end{array}$ & $\mathrm{~T}$ & $\cdots$ & 5.9 \\
\hline $\begin{array}{c}63\left(25 \mathrm{HrO}_{2}, 75 \mathrm{ZrO} \mathrm{r}_{2}\right) \\
37 \mathrm{TiO}_{2}\end{array}$ & $\mathrm{~T}$ & --- & 6.67 \\
\hline $63 \mathrm{ZrO}_{2} \cdot 37 \mathrm{TiO}_{2}$ & B & $\cdots$ & $<7.2$ \\
\hline $\begin{array}{c}63\left(33 \mathrm{Al}_{2} \mathrm{O}_{3}, 33 \mathrm{HfO}_{2}\right. \\
\left.33 \mathrm{ZrG}_{3}\right) \cdot 37 \mathrm{TiO}_{2}\end{array}$ & $\mathbf{Q}$ & $\cdots$ & 6.45 \\
\hline $\mathrm{Al}_{2} \mathrm{O}_{3} \cdot 2 \mathrm{TiO}_{2} \cdot \mathrm{Ta}_{2} \mathrm{O}_{\mathrm{B}}$ & $\mathrm{T}$ & $\cdots$ & 7.09 \\
\hline $\mathrm{Al}_{2} \mathrm{O}_{9} \cdot 2 \mathrm{HfO}_{2} \cdot \mathrm{Ta}_{2} \mathrm{O}_{6}$ & $\mathrm{~T}$ & $\cdots$ & 4.43 \\
\hline $\mathrm{Y}_{2} \mathrm{O}_{3} \cdot 2 \mathrm{TiO}_{2} \cdot \mathrm{Ta}_{2} \mathrm{O}_{6}$ & $\mathrm{~T}$ & ortho & 7.49 \\
\hline $\mathrm{Y}_{2} \mathrm{O}_{3} \cdot 2 \mathrm{HfO}_{3} \cdot \mathrm{Ta}_{2} \mathrm{O}_{0}$ & $\mathrm{~T}$ & $\cdots$ & 6.56 \\
\hline $2 \mathrm{MgO} \cdot 2 \mathrm{Al}_{2} \mathrm{O}_{8} \cdot 5 \mathrm{SiO}_{2}$ & $\mathrm{~T}$ & $\cdots$ & 8.1 \\
\hline
\end{tabular}

by atomic absorption or $x$-ray fluorescence depending on the particle size. Densities were measured on the specimens after thermal expansion data were taken. The meliting points and phase changes were observed by DTA-TGA against alumina standards. Electrical resistivity was measured before and after each thermal expansion measurement. Thermal expansion was determined using a quart $z$ push rod dilatometer over the range from rocm temperature to $1000^{\circ} \mathrm{C}$. Data from the measurements were fed to a small computer which plotted the expansion curve vs temperature. Fused silica and platinum from the NBS were used as standards. The error was estimated to be $\pm 3 \%$ of any given value.

Both IJCC and LASL have experimented with plasma spraying both the commercial and laboratory prepared powders. The plasma flame partially melts the fine particles which are then propelled toward the work piece and fuse to it in a granular covering. If the sprayed material is examined microscopically a considerable amount of c.mnected porosity is visible. The particle shape, rati is than being angular, is now a pancake shape with smooth edges and a depressed or flattened center. In addition, the material is definitely not the same stoichiometry as the powder before spraying. This ray pose a problem in that the altered

stoichiometry does not have the same expansion characteristics as the initial powder.

Methods for compensating for the altered $c \cdot$ m. position are 1) to spray a composition that, when it passes through the gun, will have been altered to the desired expansion characteristics, and 2) to reoxidize the sprayed powder by heat treating it. The former is more desirable because very often the substrate will not tolerate the oxidizing environment necessary to aclieve the presprayed CTE conditions.

Adhesion of the materials to the substrate is im. proved by grit blasting the metal prior to plasma spraying. LASL has prepared free-standing pipes, tubes, and crucibles by spraying onto copper and dissolving the copper later with acid. UCC has developed a production technicue for plasmaspraying a high-temperature crucible by spraying oxides on the inside of W-Ni-Fe mandrels. The large difference in thermal expansion allows the crucible to be removed when the part cools to room temperature. UCC also discovered that when $\mathrm{Y}_{2} \mathrm{O}_{3}$ was sprayed on the sime metal substrate, it bonded very tightly.

Plasma spraying has been used at LASL tu make most shapes of rotation. Figure 6 shows a combined cylinder and hemisphere shape which is being 


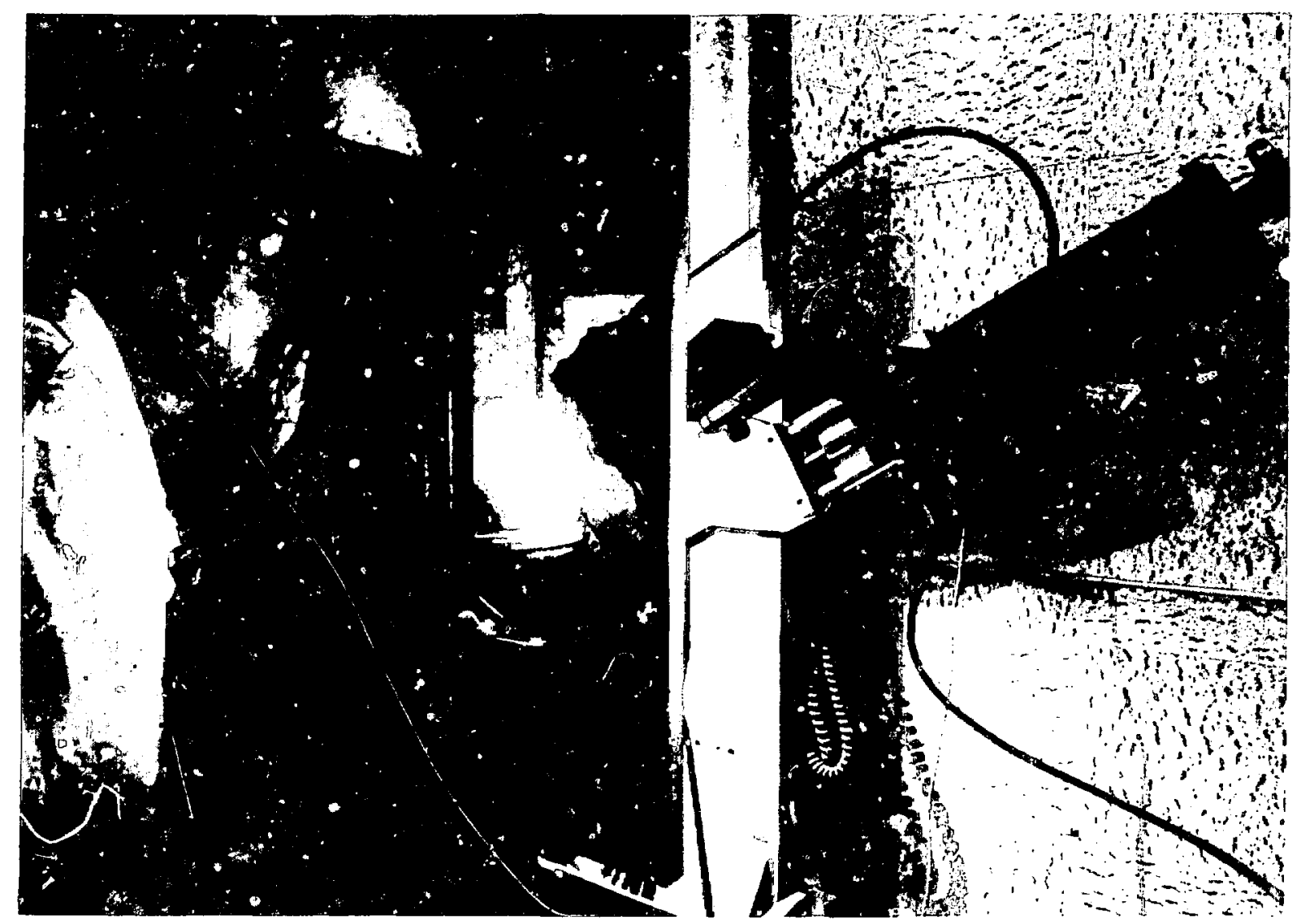

Fig. 6.

A typical shape being plasma-spraved with alumina at Los Alamos.

sprayed with a utiform coat of $\mathrm{AL}_{2} \mathrm{O}_{3}$. A small section of a spray coating like this was removed for ('TF. measurements.

\section{Common Factors Observed in Low CTE Materials}

lf one ionks carefully at these compounds for common properties in order to predict what may be caucing the low (TE. the following things are noted. The summetry of the unit cell is never cubic, very infrequently tetragomal. and in the large majority of (ases it is orthorhombic. In some cases it might even be monoclinic. Allied with this property of low symmetry are st rong axial expansions and contractions. For instance. the axial expansion in the hafniatitania sistem for ort rhombic $\mathrm{HfTiO}_{4}$ is very strongly negative along the $b$ axis. while it is moderately positive along the a axis.

The " npounds that exhibit the low expansion propercits are in large maj rity ternary or higher order combiations indicating there is probably an innuence from the elecironic configuration of the metal atoms on an atomic scale, just as there is an influence from the atom positions in the laitice on a molecular scale. The structures however are not complicated. They contain lots of npen space similar to glasses. All of the compounds investigated by us and most of the ones investigated by others have melting points $\geq 1400^{\circ} \mathrm{C}$. The hafnia-titania system contains a composition at about $45 \% \mathrm{TiO}_{2}$ that is single-phase material from room temperature to $\sim 28(6)^{\circ} \mathrm{C}$. This is a greater range than any other known compound. 
Many people haie attributed the curious expansion behavior to microcracking of the grains in these materials. In our very pure $\mathrm{HfO}_{2}$ study, we were unable to detect any microcracks, ${ }^{20}$ and Holcombe has had difficulty observing microcracks in the material he has studied. In contrast, however, the hysteresis behavior that is characteristic of the CTE with successive thermal cycles is present in most of these samples. Holcombe ${ }^{21}$ has speculated on possible mechonisms of "plastic flow" that migh" cause this behavior to occur and without exhibiting microcracks. (See Appendix.) Blendell and Coble ${ }^{22}$ while studying $\mathrm{Al}_{2} \mathrm{O}_{3}$ have described a stress relaxation phenomenon related to grain size. The two hypotheses are related and are of interest to others but will not be elaborated on here.

\section{APPENDIX}

\section{HOLCONBE'S "PRINCIPLES"21}

1) The structure contains chains or spirals of corner-bonded polyhedra in the lowest expanding or contracting direction. This direction may not coincide with a principal anis of the unit cell, therefore the contraction may be vectorally divided along axial directions.

2) Channels (tunnels or structural voius) must exist in the structure. The open structure permits stuffing of the lattice with small cations without affecting the CTE appreciably. When the lattice becomes filled, the CTE will increase. This behavior has been observed in $\mathrm{Ba} \sim 4 \mathrm{Na}_{\sim 2} \mathrm{Nb}_{10} \mathrm{O}_{90}$, a stuffed analog of tungsten bronze manifested in nature by the pyroxenes and zeolites.
3) Tilting of polyhedra is restricted to the direction of channels by a "symmetry clamping" effect. The more restricted the tilt is in the direction of the channel, the smaller the thermal expansion.

4) Polyhedra are distorted and tend to reduce the distortion when heated thus tending to equalize the bond ' 1 gth. The degree of distortion depends on a) cation-anion bond length, b) substitution of differing size cations in specific sites of neighboring polyhedra, c) edge bonding, and d) anion deficiency. This implies that the polyhedral distortion, thus CTE. can be controlled by solid solution as has been demonstrated by Merz et $\left.a\right|^{23}$ and by Holcombe with $\mathrm{HfO}_{2}$ in $\mathrm{Ta}_{2} \mathrm{WO}_{3}$.

\section{KEFERENCES}

1. N. A. Godina, E. K. Keler, and V. S. Ruuenko, "Reaction Between Hafnium and Titanium Dioxides," J. Inorg. Chem., (USSR) 512 1349-50 (1960).

2. F. H. Simpson, "High Temperature Structural Ceramics," Mater. Des. Engr., 52, 2 16-18 (1960).

3. R. W. Lynch and Bruno Morosin, "Thermal Expansion, Compressibility and Polymorphism in Haínium and Zirconium Titanates," J. Am. Cer. Soc., 558 409-13 (1972).
4. Robert Ruh, G. W. Hollenberg, E. G. Charles, and V. A. Patel, "Phase Relations and Thermal Expansion in the System $\mathrm{HfO}_{2}-\mathrm{TiO}_{2}$," J. Am. Cer. Soc., 59 11-12 495-499 (1976).

5. R. G. Hoagland, C. W. Marschall, A. R. P.ssefield, G. W. Hollenberg, and Robert Ruh, "Microstructural Factors Influencing Fracture Toughness of Hafnium Mitanate," Mater. Sci. Engr., 15151.62 (1974).

6. J. L. Anderson, R. A. Briesmeister, S. R. Skaggs, G. A. Carlson, and Robert Ruh, "Coefficient 
of Thermal Expansion and Dynamic Response to Pulsed Energy Deposition in $\mathrm{HfO}_{2}-\mathrm{TiO}_{2}$ Compositions," submitted to the .J. Am. Cer. Soc., for publication.

7. K. J. Lawerance and D. S. Mason, "WONDY IV-A Computer Program for One-Dimensional Wave Propagation with Rezoning," Sandia Laboratories Research report SC-RR-71-0284, (1971).

8. S. R. Straggs, W. B. Hall, and R. S. Thurston, Los Alamos Scientific Laboratory, unpublished results on hafnium-titanate properties.

9. Personal communication Tom Reed to S. R. Skaggs June 1971, including several samples of different Ti-O stoichiometries.

10. R. F. Geller and Paul J. Yavorsky, "Effects of Some Oxide Additions on the Thermal Length Changes of Zirconia," J. Res. NBS, 35 87-110 (1945).

11. R. B. Burdick and W. R. Hoskyns, "Research on the Thermal Properties of Zirconia," USAF Report ARL-63-17072 pp. (1970).

12. C. E. Curtis, L. M. Doney, and J. R. Johnson, "Some Properties of Hafnium Oxide, Hafnium Silicate, Calcium Hafnate, and Hafnium Carbide." J. Am. Cer. Soc., 37, $10458-465$ (1954).

13. Clark F. Grain and William J. Campbell. "Thermal Expansion and Phase Inversion of Six Refractory Oxides." U.S. Bureau of Mines Report of Investigation 5982 (1962).

14. Basil Ohnysty and F. K. Rose. "Thermal Ex. pansion Measurements on Thoria and Hatnia to 4500 F." J. Am. Cer. Soc., 47, 8 398-400 (1964).

15. R. N. Patil and F. C. Subbarao, "Axial Thermal Expansion of $\mathrm{ZrO}_{2}$ and $\mathrm{HfO}_{2}$ in the Range Room Temperature to $1400^{\circ} \mathrm{C}$, J. A Appl. Cryst., 2, 281.288 (1969).
16. S. K. Filatov and V. A. Frank-Kamanetskii. "Anamulous Thermal Expansion of $\mathrm{ZrO}_{2}$ and $\mathrm{HfO}_{2}$ over the Range $20-1200^{\circ} \mathrm{C}$," Soviet PhysicsCrystallography (Kristallografia) 14, 5 696-699 English Translation (1970).

17. Denzil W. Stacy, J. Keith Johnstone, and D. R. Wilder, "Axial Thermal Expansion of $\mathrm{HfO}_{2}$," J. Am. Cer. Soc., 5s, 9 482-483 (1972).

18. C. E. Holcomive, M. K. Morrow, D. D. Smith, and D. A. Carpenter, "Survey of Low Expanding High Melting Mixed Oxides," Union Carbide Corporation Y-12 Plant Research report Y-1913 (1974).

19. K. S. Masdiyasni, C. T. Lynch, and J. S. Smith, "Development of New Ceramic Materials (Zyttrite) by Thermal and Hydrolytic Decomposition of Metal Alcoholates," USAF Materials Laboratory report AFML-TR-66-418 (1966).

20. Rubert Ruh, G. W. Hollenberg, Frank D. Gac, Stephen D. Stoddard, and S. R. Skaggs, "Comparison of the Thermal Expansion of Zirconia and Hafnia," to be published.

21. r. E. Holcombe, D. D. Smith, H. L. Richards, and I. D. Lore, "Properties of Thermally Contracting Tantalum Tungstates, "Union Carbide Corporation Y-12 Plant Researcn report Y-2071, (1977).

22. John E. Blendell, R. L. Coble, and R. J. Charles, "On the Relaxation of Stresses Arising from Thermal Expansion Anisotropy During Cooling Polycrystalline Materials," Proceedings of the $6 \mathrm{th}$ International Symposiun on Microstructure of Ceramic Materials, Berkeley, Califurnia (1976).

23. K. M. Merz, W. R. Brown, and H. P. Kirchner, "Thermal Expansion Anisotropy of Oxide Solid Solu ions," J. Am. Cer. Soc., 45, $11531-536$ (1962). 